\title{
Embracing New Media in Political Communication: A Survey of Parliamentarians Attitudes and Practices in a Changing Media Landscape in West Africa
}

Aminu Hamajoda*

National Institute for legislative Studies, Nigeria

\begin{abstract}
This survey sought to find out the state of political communication among West African parliamentarians in view of the expanded mediality that newer digital channels like social media, the internet and mobile telecommunication tools are bringing to the political landscape in addition to traditional political channels of party politics, rallies, meetings, constituency visits and traditional media like television, radio and newspapers. The study had deliberately focused on the three core parliamentary functions; lawmaking, representation and oversight, asking key questions under each function to delineate the views and practices of legislators in using media channels. Findings from this study show that although there is a remarkable improvement in acquisition of tools, legislators are reticent in deploying the full powers of new channels in interaction with citizens, preferring traditional channels like television and radio in activity propagation and political meetings and constituency visits to newer tools like e-petition, e-consultation, blogging, personal websites, e-polling and other forums. However there are evidences of rising Facebook use and intensive use of telephony and text messages in communicating with constituents. There are also evidences of the increased use of emails and internet research in gathering information for lawmaking.
\end{abstract}

Keywords: Digital media; Political communication; Legislators attitude; Parliamentary communication; Changing media landscape

\section{Background to Study}

Numerous studies show how African politicians can potentially benefit from modern electronic platforms, especially with the decreasing importance of parties as means of political communication and mobilization. Several studies [1-3] argue that interactive communicative platforms (websites, emails, SMS, blogs, Facebooks, Twitter, Photo and Video sharing, Messaging, etc.) can open up channels of interaction between the electorates and legislators, quite often in real time. By so doing, they argue, legislators as representatives can sharpen their skills in all forms of communication - written, oral and visual.

The electorate on the other hand can also benefit by participating and influencing decision and policy making processes. Unwin [4] delineates the unmissable potentials of the new digital and social media in political empowerment as space-liberty; the potential freedom of communicating with others across the globe, sharing liberty; the widespread creation and sharing of information and views as against the traditional top-to-bottom communication of government/ corporate owned channels, and access-liberty; the reduction in cost in the creation and dissemination of information as exemplified by the new cellular phones that are equipped with audio and visual recorders coupled with internet connection.

Indeed Information and communication technology is developing rapidly in sub-Saharan Africa despite glaring infrastructural constrains. Several reports $[5,6]$ confirm the exponential growth of ICT especially the 'mobile revolution' that is penetrating the region and affecting all areas of life. But there are still challenges to overcome in regard to engaging sub-Saharan citizens in deliberative democracy.

The first challenge is the issue of poor network connection. The bandwidth challenge in sub-Saharan Africa is slowing the full impact of the exponential growth experienced in digital technology and the new media. Although Zamfir [5] documents the improved linkage of Africa to the rest of the world through submarine cables, evacuating the broad bandwidth advantage to hinterland and especially landlocked countries like Mali and Central African Republics remains a challenge.

The second challenge is dearth of knowledge and digital skills that tend to compound the digital divide. The lack of ICT skills cut across both supporting professionals, the politicians themselves and the electorate. The mere presence of new digital tools is not enough, but their full utilization to achieve functional purposes that are positive to both the communicator and the communicate. IPU [6] report says, it is 'skills and training that are seen (by 61 percent of parliaments) as the most significant challenges for members trying to communicate with citizens using digital tools'.

The third challenge is what appears to be the politicians' selfish approach to the utilization of the new digital media. Frank [7] mentions the habit of Kenyan politicians who create personal websites during elections but who abandon them after elections. It appears as if short term political calculations are given priority over long term plan to build an electoral base. This hit-and-run approach to using new media pervades the whole gamut of sub-Saharan e-democracy activities. In Nigeria for instance, politicians change their phone numbers and emails upon being elected, appointed or tried. Of course this may be attributed to the next challenge, risk.

*Corresponding author: Hamajoda A, National Institute for legislative Studies (NILS), Maitama, Abuja, Nigeria, Tel: 08114579389; E-mail: aminufhamajoda@yahoo.com

Received July 23, 2016; Accepted July 28, 2016; Published July 29, 2016

Citation: Hamajoda A (2016) Embracing New Media in Political Communication: A Survey of Parliamentarians Attitudes and Practices in a Changing Media Landscape in West Africa. J Mass Communicat Journalism 6: 310. doi: 10.4172/21657912.1000310

Copyright: (c) 2016 Hamajoda A. This is an open-access article distributed under the terms of the Creative Commons Attribution License, which permits unrestricted use, distribution, and reproduction in any medium, provided the original author and source are credited. 
The fourth challenge is the danger of uncontrolled interaction which MacNamara et al. [1] regard as pitfalls that may accompany the creation of a new media site specifically crafted for interaction with the citizens, among which are possibilities of vitriolic criticism and defamation of individuals and organizations; encounters that will make parliamentarians shudder and be reticent. Olabamiji [8] also documents the dysfunctional use of the social media in Nigeria in maligning, intimidating and discrediting political opponents, thereby creating a milieu for subsequent violent political and social conflicts.

The fifth challenge is the dominance of the traditional channels of communication. Most politicians still prefer the uni-directional media channels like television, radio and print. Robert and Namusonge's [9] study of East African Parliamentarians affirm their overwhelming trust in traditional media.

The last challenge is the faulty assumption that once interactivity is established between representatives and constituents, mutual inputs are guaranteed in law and policy making. Duffy and Foley [10] however conclude that citizens are not equipped or interested in extensive input to public hearings, although there is a possibility of limited engagement on topical issues that are of general interest to the public or issues of self-interest. Fox [11] in his seminal report also observes the poor percentage of citizens who have visited the parliament website or have partaken in policy decisions, thereby concluding that "The problems with political engagement cannot be solved by technology / digital initiatives; they are part of the solution but not the solution".

\section{Methodology}

This study is based on a questionnaire survey that attempted to sample legislators' views and practices in using contemporary communication channels in carrying out their representation, lawmaking and oversight functions. The survey had relied on some key pointers under the triangle of functions.

Under capacity and ITC support, the study sought to find out: a) the digital communication tools possessed by the parliamentarians, b) how satisfactorily equipped their legislative offices are, and c) the challenges they face in using available tools.

Under representation, the parliamentarians were asked many more several questions: a) how often they use new media for political communication with citizens by rating, b) how often they use new media as compared to traditional methods in gathering and polling opinions of their constituents on burning issues, policies and bills, c) How they propagate their legislative activities using new media vis-àvis using traditional media, $d$ ) if they use any specific digital/new media for communicating with the youth, e) how they rate the effectiveness of parliamentary communication of its activities and f) which channels they rank in preference for parliamentary propagation.

Under the function of lawmaking, the study asked a) how parliamentarians gather information for lawmaking considering the additional new channel of internet research in relation to existing parliamentary resources like libraries, consultants and NGOs.

The study also inquired about (b) how the legislators get information from government agencies for purposes of oversight considering the current expanded mediality of channels and forms of information.

The questionnaire was translated into both French and Portuguese, the other two languages used in the West African Region. The study then created a receptacle database based on the form and subjected collected data to various analyses; mainly frequency, cross tables, graphic summaries, and few dependency variations to reveal the various attitudinal and usage patterns.

The survey targeted the first session of the yearly ECOWAS Parliament sitting when 115 legislators from the 15 member states attended a sitting in Abuja, Nigeria. Below is the actual seats allocated to the various member states and the number of respondents (Table 1).

\section{Results and Discussions}

\section{Capacity, facilities and the digital divide}

Over $83 \%$ of parliamentarians range between the ages of 45 to 64 years, the range already acknowledged by IPU [12] as the lowest in the world, but it is difficult to ascertain if age is an additional imperative in embracing the new media in relation to other constraints like lack of skills, poor connections and citizens' lack of access to the internet as Table 3 shows. A cross variation analysis show that those above 55 years do not select the internet as their means for propagating their activities and do not use any digital based methods for communicating with the youth despite the continuous promotion that youth form the backbone of the new media users in Africa (Table 2).

To be sure, the study shows that Legislators are well equipped to communicate with their constituents considering that over $70 \%$ of them have laptops and internet devices. Similarly the survey reveals that $71.43 \%$ of legislators' offices are equipped with desktop computers, $59.52 \%$ have adequate printing services, $66.67 \%$ have adequate telephony and $59.52 \%$ have adequate internet facilities.

These findings compared better to previous studies that show dire ICT situations in African parliaments yet $65 \%$ legislators complain of

\begin{tabular}{|l|c|c|c|c|c|}
\hline \multicolumn{1}{|c|}{ Country } & Seats & Respondents & Country & Seats & Respondents \\
\hline Ghana & 8 & 2 & Niger & 6 & 3 \\
\hline Guinea & 6 & 3 & Nigeria & 35 & 6 \\
\hline Guinea Bissau & 5 & 2 & Senegal & 6 & 3 \\
\hline Liberia & 5 & 2 & Sierra Leone & 5 & 1 \\
\hline Mali & 6 & 4 & Togo & 5 & 4 \\
\hline Cape Verde & 5 & 3 & Burkina Faso & 6 & 3 \\
\hline Gambia & 5 & 4 & Benin & 5 & 2 \\
\hline Ivory Coast & 7 & 3 & & & \\
\hline
\end{tabular}

Table 1: Targeted legislators and actual number of responders.

\begin{tabular}{|l|c|c|c|}
\hline $\begin{array}{l}\text { Do You Use Any Digital Based } \\
\text { Methods to Communicate With Youth }\end{array}$ & Frequency & Percent & Cum. Percent \\
\hline No & 29 & $66 \%$ & $66 \%$ \\
\hline Considering & 10 & $23 \%$ & $89 \%$ \\
\hline No and Not considering & 5 & $11 \%$ & $100 \%$ \\
\hline Total & 44 & $100 \%$ & $100 \%$ \\
\hline
\end{tabular}

Table 2: Communicating with the youth

\begin{tabular}{|l|c|c|}
\hline $\begin{array}{l}\text { What are the main challenges you face using digital } \\
\text { tools to communicate with }\end{array}$ & Frequency & Percent \\
\hline Lack of skills and training to use digital tools & 29 & $65.91 \%$ \\
\hline Citizens lack Access to Internet & 25 & $56.82 \%$ \\
\hline Privacy issue in technology use & 18 & 40.91 \\
\hline Lack of Access to Internet & 16 & 36.36 \\
\hline $\begin{array}{l}\text { Trying to give Equal Priority to on and off line } \\
\text { Communication }\end{array}$ & 9 & 20.45 \\
\hline Communication received is unrepresentative & 8 & 18.18 \\
\hline Feeling overwhelmed with Quantity of Communication & 7 & 15.91 \\
\hline
\end{tabular}

Table 3: Main challenges parliamentarians face in communicating with their constituents. 
the lack of skills and training to the use of digital tools while over $56 \%$ complain of access to internet by their constituencies. The problem of internet connection in West Africa is twofold. The complete absence of connection and the extremely low bandwidth that cannot even support rudimentary services like checking emails. According to the International Telecommunication Report, as Zamfir [5] documents, Niger, Guinea, and Sierra Leone have less than 5\% internet Users among their population, and generally west and central African countries fair badly in internet connection when compared to East and Northern Africa. However this survey shows how adequately equipped parliamentarians generally are both in terms of their persons and their legislative offices, except for Sierra Leone. It is pertinent to note that the issue of privacy in communication crops up (Table 3 ) after lack of skills and lack of citizens access to internet. It is ironic that as new digital media is becoming universally ubiquitous, the issue of privacy and lack of established ethics are making parliamentarians reticent in using interactive media for fear of damage to their reputation and image.

\section{Representation}

The drive by parliaments to engage the public sphere can be categorized into two endeavors as Power [3] points out. One; the desire to consult and involve the public in the work of the parliament and two; the desire to provide information and improve public understanding of the work and achievements of parliaments.

The prospect of parliamentarians embracing new channels of communication to ensure a broad-based link with constituents in ensuring popular democracy is exciting. Not only will decisions on bills and policies be collective and reflective of electorate but it will ensure that parliamentarians go beyond representation to be continuous delegates on the national fora. The survey listed the various forms of the new media to find out the extent of their use in political communication by West African parliamentarians (Figure 1).

By ranking, Personal Emailing, Facebook and Messaging form the main digital channels parliamentarians use for political communication with their constituents. The other channels ranging from contact forms to video sharing are still far from being popular among West African Parliamentarians.

Not less than $60 \%$ of parliamentarians signify that they use personal emails to communicate with constituents, $40 \%$ messaging and $56 \%$ using face book. IPU [6] reports 56\% of legislators worldwide using the new media as compared $13 \%$ in 2010 , but confirms that the rest of the tools are either under consideration or not planned for at all. Three factors may contribute to West African parliamentarians not using the other eight or more tools, one is, there are not existing on official parliamentary websites or, two, personal websites are not create by the

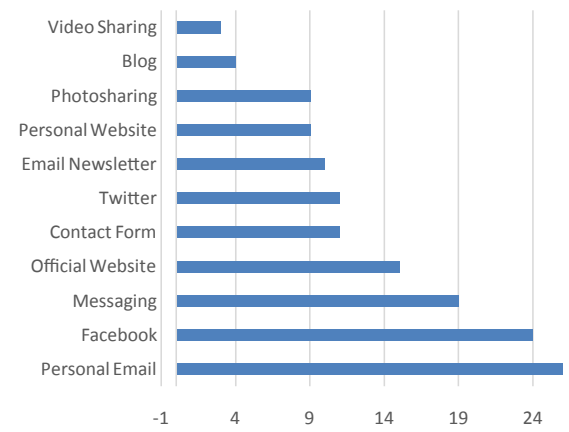

Figure 1: Use of new media for political communication. lawmakers or, three, and most significantly, constituents have no access to the internet. In a report by National Democratic Institute, NDI [13], a Ghanaian MP reiterates the prevalent use of text messaging among Ghanaian MPs but raised the issue of illiteracy among women as his reason for preferring traditional channels like radio and television. This indeed is confirmed by the parliamentarians' preferences for propagating their activities (Figure 2).

Not surprisingly, traditional channels are preferred in the propagation of individual parliamentarians' activities. Radio ranks number one as the preferred channel followed by Television. 59\% of parliamentarians still prefer the traditional media (Radio, TV and Print) in propagating their activities to new channels like personal websites, YouTube and blogging, although the internet followed by messaging are gaining ascendency. A cross tabulation shows that most of the elderly parliamentarians between the ages of 55 to 75 do not use the internet for propagation. Williamson notes how parliamentarians globally focus more on self-promotion and one-way reportage as against devising strategies to enhance interactive engagement with the electorate (Figure 3).

Similar attitude attend to their views on publicity for the parliament. $79 \%$ rank radio and television as the best medium for publicizing parliamentary activities as against other channels like education, web services, mobile platforms, conferences and blogging. There is a certain level of reticence that although is unquantifiable among African parliamentarians, is further confirmed by their tendency to insularity and preference to directional communication after they are elected. This has also been confirmed by Robert and Namusonge's [9] study of East African Parliamentarians. However a pragmatic view that the

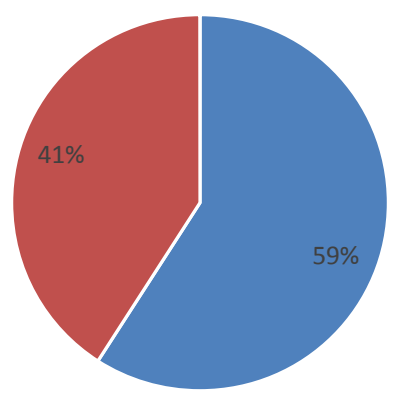

- Traditional Media $\quad$ new Media

Figure 2: How do you propagate your parliamentary activities?

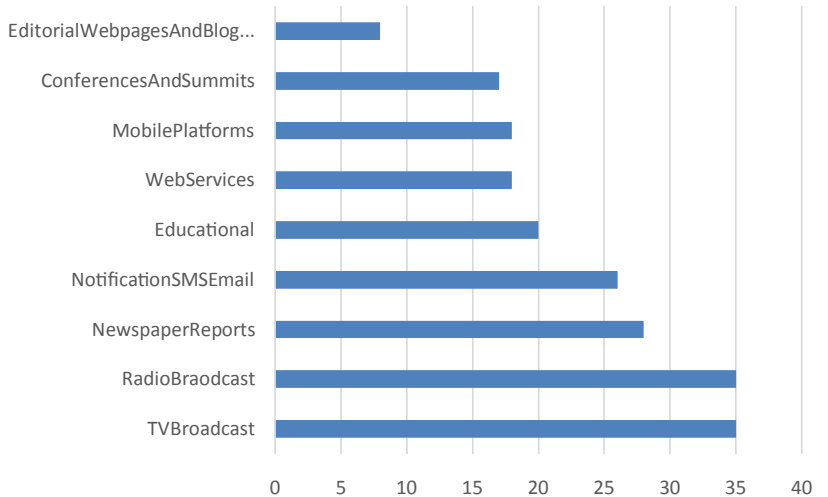

Figure 3: Preferred media for parliamentary publicity. 
lawmakers prefer directional communication due to the reach the traditional channels like radio and television still have among their constituents is not less valid.

\section{Lawmaking}

Lawmaking is the cardinal role of parliamentarians around which several services are designed to equip them to perform their functions efficiently. Research and policy analysis are areas that various capacity building efforts are targeted at. Parliamentarians have arrays of services to choose from: parliamentary researchers, legislative aides, parliamentary institutions and parastatals and of course, personal research and opinions of their constituents (Figure 4).

The survey shows that the internet rank as the most preferred means of gathering information for legislation by the parliamentarians (54\%) followed by parliamentary researchers $(45 \%)$ and NGOs and Civil societies (45\%).

On polling constituents on issues, bills and policies, digital media scores $66 \%$ mainly because of mobile telephony but by ranking traditional channels of opinion leaders, political meeting, delegates and visits by legislators still are uppermost in polling constituents. It is apparent from Figure 5 that telephony, SMS Text and social networking sites are specifically the new digital channels that are gaining ascendancy in gathering opinions from constituents by legislators. The

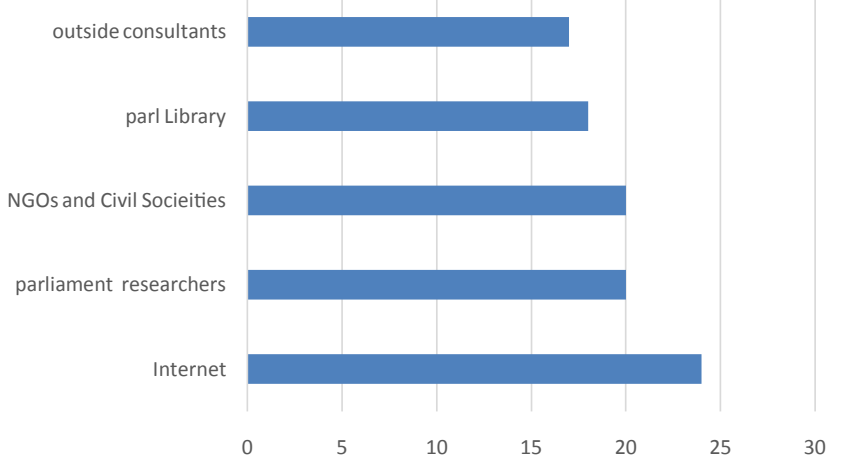

Figure 4: Means of gathering information for legislation.

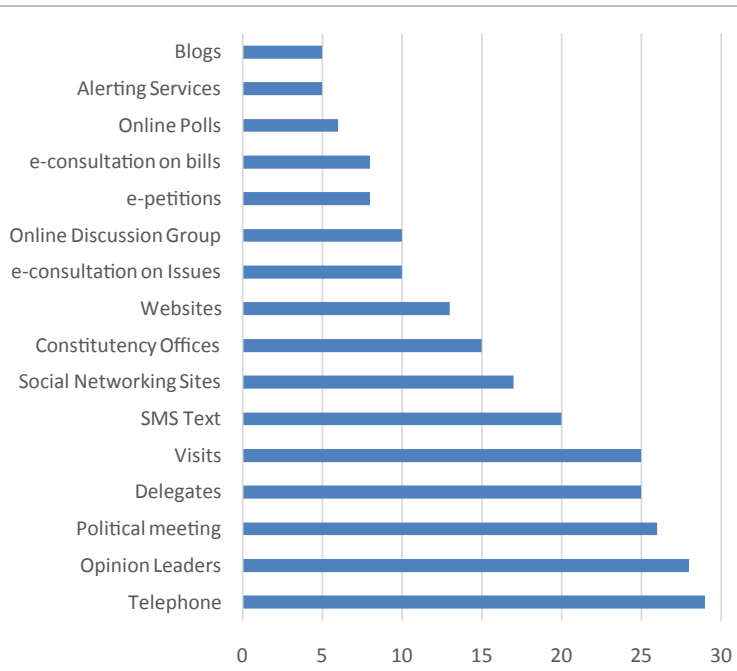

Figure 5: Polling constituents on issues, policies and bills.

\begin{tabular}{|l|c|l|}
\hline $\begin{array}{l}\text { How do you get information from government for } \\
\text { oversight purposes }\end{array}$ & Frequency & Percent \\
\hline Electronic Copies Through Emails & 23 & $52.27 \%$ \\
\hline Hard copies Through Messenger & 21 & $47.73 \%$ \\
\hline Telephone Conversations & 17 & $38.74 \%$ \\
\hline Soft copies Through Portable Devices & 12 & $27.27 \%$ \\
\hline Others & 10 & $22.73 \%$ \\
\hline
\end{tabular}

Table 4: Gathering information from government for oversight.

phenomenal growth of mobile telephony in Africa especially coupled with their inclusion of internet and extended messaging forums could bridge the so- called digital divide. Cell phones in several ways helped Africans to jump the enormous infrastructural obstacles of power supply, low bandwidth and knowledge base. All studies $[3,7]$ acknowledge the enormous use of cell phones and text messages in political communication as against the slow encumbered development of the internet technology. Hybrid mobile phones are further absorbing the interactive tools of the internet like twitter, Facebook, messaging, blogging and a fair amount of audio and video on to the rugged telephony platform. In general as Frank [7] points out, the emerging user groups "can no longer be described as elite".

\section{Oversight}

Oversight of the activities of the government agencies forms a very important function of the parliament. Although public hearings, committee work and oversight tours remain central to oversight exercise, as Yamamoto [14] points out, "Regular questioning can be used by parliament to hold the government to account". Regular questioning is easier for non-presidential parliaments, but for lawmakers in presidential systems, questioning in oral and written forms for details takes on a different challenge since the president and his ministers are outside the parliament. It appears pertinent for legislators to be equipped with information at the personal level to be able to partake in hearings, committee work and plenary sessions [15]. This study therefore sought to find the communication channels parliamentarians use in requesting and receiving adhoc inquiries and written questions for details and clarifications from government (Table 4). The result shows that email correspondence in addition to telephone conversations is getting established in inquiries and information gathering from government agencies.

\section{Conclusion}

It is pertinent for ECOWAS parliaments to deliberately set out to strengthen communication channels between lawmakers, the electorate and government agencies in view of the imminent expansion of mediality that telecommunications and the new digital media portent. In doing so, the channels under each parliamentary function should be assessed for facilitation. The various parliamentary websites need to be upgraded to host interactive tools like e-consultation, online discussions, e-petitions, on-line polls and alerting services. Legislators and their media aides should be trained specifically on those platforms and be supported in creating individual websites with the relevant forms and widgets enumerated above. Similarly training and sensitization of the parliamentarians and support staff should aim at functional groundings to eliminate the tendency to insularity.

\section{Acknowledgement}

This study was officially permitted by both the National Institute for Legislative Studies (NILS) and by the ECOWAS Parliament. I am thankful to Martin Ani, a Research Assistant, who was assigned to support the administration of the questionnaires. 
Citation: Hamajoda A (2016) Embracing New Media in Political Communication: A Survey of Parliamentarians Attitudes and Practices in a Changing Media Landscape in West Africa. J Mass Communicat Journalism 6: 310. doi: 10.4172/2165-7912.1000310

\section{References}

1. Macnamara J, Sakinofsky P, Beattie J (2012) E-lectoral Engagement: Maintaining and Enhancing Democratic Participation through Social Media Report to the Australian Electoral Commission by Australian Centre for Public Communication, University of Technology, Sydney.

2. Kingham T (2003) e-Parliaments: The Use of Information and Communication Technologies to Improve Parliamentary Processes. World Bank Documents and Reports 1: 1-39.

3. Power G (2012) Global Parliamentary Report: The Challenging Nature of Parliamentary Representation. UNDP/IPU, Inter-Parliamentary Union IUnited Nations Development Programme, Denmark.

4. Unwin T (2012) Social Media and Democracy: Critical Reflections. Background Paper for Commonwealth Parliamentary Conference, Colombo.

5. Zamfir L (2015) Digital Development in Sub-Saharan Africa. EPRS European Parliamentary Research Service.

6. IPU (2016) World e-Parliament Conference 2016. IPU, Geneva

7. Windeck F (2010) Political Communication in Sub-Saharan Africa and the Role of New media.
8. Olabamiji O (2014) Use and Misuse of the New Media for Political Communication in Nigeria's 4th Republic. Developing Country Studies 4: 44-53.

9. Robert A, Namusonge GS (2015) The Use of Information And Communication Technology, And Social Networking Sites In Political Governance of East African Legislative Assembly Parliament. International Journal of Scientific \& Technology Research 4: 136-143.

10. Duffy B, Foley M (2011) Social Media, Community Engagement and Perceptions of Parliament: a Case Study from the NSW Legislative Council. Australasian Parliamentary Review 26: 198-206.

11. Fox R (2014) Evidence to the Speaker's Commission on Digital Democracy. Hansard Society.

12. NDI (2015) Twenty MPs Participate in Parliamentary Exchange on Leadership in the Digital Economy.

13. Yamamoto H (2007) Tools for Parliamentary Oversight: A Comparative Study of 88 National Parliaments. Inter-Parliamentary Union, Switzerland.

14. Munatsi R (2011) E-skills for Progressive Governance: Supporting Evidenceinformed Policy Making in African Parliaments. IFLA, San Juan.

15. Williamson A (2009) The Effect of Digital Media on MPs' Communication with Constituents. Parliamentary Affairs 62: 514-527. 